\title{
BCL2L2 wt Allele
}

National Cancer Institute

\section{Source}

National Cancer Institute. BCL2L2 wt Allele. NCI Thesaurus. Code C49351.

Human BCL2L2 wild-type allele is located within 14q11.2-q12 and is approximately 5kb in length. This allele, which encodes apoptosis regulator Bcl-W protein, is involved in apoptotic regulation. 